\title{
Epidemiological and Control Aspects of Schistosomiasis in Brazilian Endemic Areas
}

\author{
JR Coura/ ${ }^{+}$, RS Amaral*
}

Departamento de Medicina Tropical, Instituto Oswaldo Cruz-Fiocruz, Av. Brasil 4365, 21045-900 Rio de Janeiro, RJ, Brasil *Programa de Controle da Esquistossomose, Secretaria de Vigilância em Saúde, Ministério da Saúde, Brasília, DF, Brasil

The present work analyzes the epidemiology of schistosomiasis in Brazil, its expansion, the attempts to control the disease, and the overall difficulties. The authors present the distribution of schistosomiasis intermediary hosts in Brazil, the migration routes of the human population, and disease distribution in highly and lowly endemic areas and isolated foci. They also analyze the controlling programs developed from 1977 to 2002, indicating the prevalence evolution and the reduction of disease morbi-mortality. In addition, the authors also evaluate controlling methods and conclude that: (a) no isolated method is able to control schistosomiasis, and every controlling program should consider the need of a multidisciplinary application of existing methods; (b) in long term, basic sanitation, potable water supply, as well as sanitary education, and community effective participation are important for infection control; (c) in short term, specific treatment at endemic areas, associated with control of intermediary hosts at epidemiologically important foci, are extremely relevant for controlling disease morbidity, although not enough for interrupting infection transmission.

Key words: schistosomiasis - epidemiology and control - Brazil 1977-2002

According to the World Health Organization, schistosomiasis is a millenary disease, which affects more than 200 million individuals distributed in 76 countries in Africa, Asia or America. Among these, $10 \%$ present the severe form of disease and 50 to $60 \%$ of infected people, that is more than 100 million people, present clinical manifestations of the disease, constituting a huge public health problem (WHO 1993).

Although discovered only in 1851 , by Theodore Bilharz, who confirmed the presence of the worm known today as Schistosoma hematobium in mesenteric vessels of an autopsied Egyptian peasant, Shistosoma eggs was found in Egyptian mummies dating from 3500 b.C. Despite, the Katayma syndrome described by Fuji in 1847, four years earlier than Bilharz's discovery, it has only been identified as the acute form of $S$. japonicum infection, much later. In 1902, Manson found eggs with lateral spine, in patients from Antilles, admitting a new species of Schistosoma, which was classified as S. mansoni, by Sambon, in 1907. This same species had its presence confirmed in Brazil, through the description of four cases, the first ones registered by Pirajá da Silva, at Bahia, in 1908.

In spite of Katayama syndrome has been described in Japan since 1847, it was only in 1914 that mollusks of Oncomelamia genre were pointed out as intermediary hosts of S. japonicum (Miyairi \& Suzuki 1914) and, in 1915, Leiper identified Bulinus and Biomphalaria, in Africa, as intermediate hosts of $S$. haematobium and $S$. mansoni, respectively.

\footnotetext{
$\overline{{ }^{+} \text {Correponding author. Fax: }}+55-21-2280.3740$. E-mail: coura@ioc.fiocruz.br

Received 28 May 2004

Accepted 26 July 2004
}

There are six species of Schistosoma that may infect a human being: S. mansoni, S. hematobium, S. japonicum, S. intercalatum, S. mekongi, and S. malayensis; but only one of them exists in Brazil, S. mansoni. In addition, from the ten species and one subspecies of Biomphalaria genre here described, three of them are natural intermediate hosts (B. glabrata, B. tenagophila, B.straminea) and two (B. amazonica, $B$. peregrina) are considered potential intermediate hosts, once they have only been infected experimentally (Paraense 1966, 1981).

\section{SCHISTOSOMIASIS IN BRAZIL}

The African slaves' traffic, probably introduced schistosomiasis in Brazil soon after the country discovery, and the migratory flows were responsible for spreading it from seashore to interior. Fig. 1 shows the migratory flows in Brazil and the distribution of intermediary hosts $B$. glabrata, B. straminea, and B. temagophila, as well as the risks of endemic expansion (Araújo 1986, Paraense 1986). Fig. 2 shows today distribution of schistosomiasis, according to prevalence rate. Nowadays, schistosomiasis transmission occurs in a vast endemic area, from Maranhão to Espírito Santo, and Minas Gerais. There are also exclusively isolated foci in the Federal Discrict and in the states of Pará, Piauí, Goiás, Rio de Janeiro, São Paulo, Paraná, Santa Catarina, and Rio Grande do Sul. In addition, there are cases imported from endemic area registered in almost all national territory, mainly, in the states that are considered points for migration, as Rondônia.

After Pirajá da Silva having described the first cases of schistosomiasis in Brazil, in 1908, it was only in 1916 that the work of Adolpho Lutz $(1916,1919)$ about $S$. mansoni's cercarias, its intermediary hosts, parasite biology, and diagnosis methods was retaken. Lutz and Penna (1918), during a mission of the Instituto Oswaldo Cruz, elaborated a broad report about the disease epidemiology in the Northeast region. Heraldo Maciel $(1924,1925)$ 


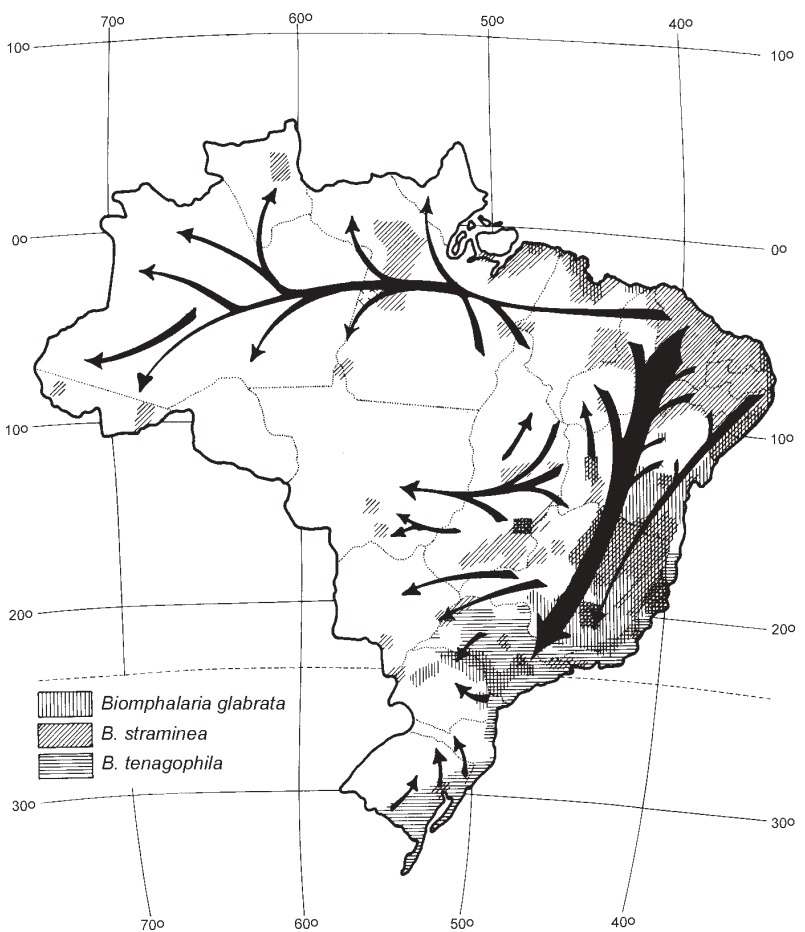

Fig. 1: human migratory flows and distribution of schistosomiasis mansoni intermediate hosts in Brazil

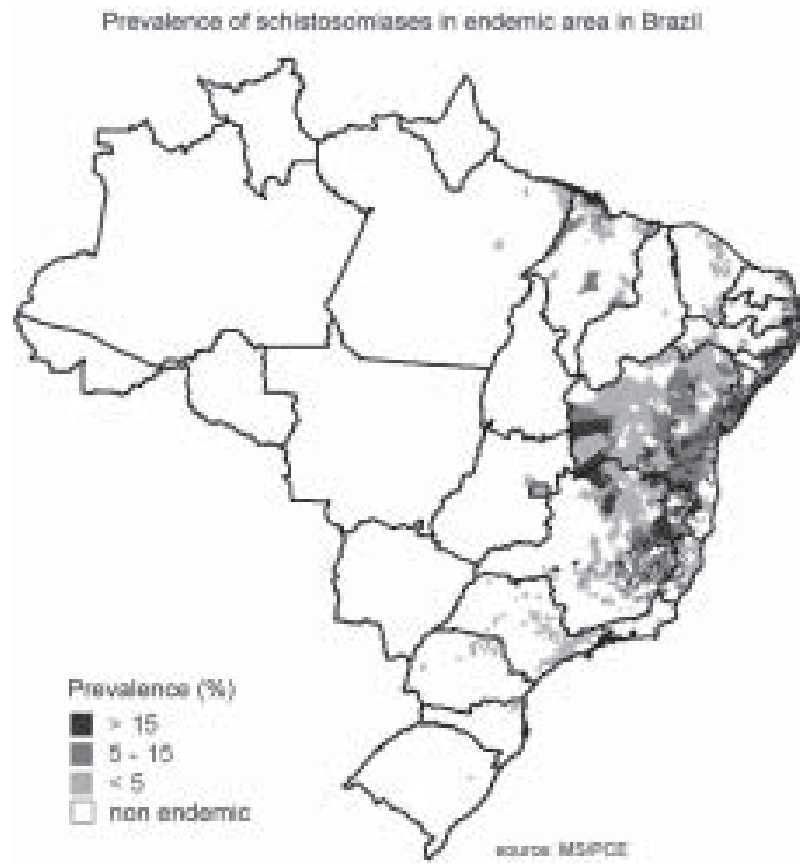

Fig. 2: distribution of schistosomiasis according to prevalence of human infection in Brazil

confirmed information about the disease and its treatment, and Madureira-Pará (1949), after examining 267.102 species of liver through viscerotomy all over the country, from 1937 to 1946, during a yellow fever vigilance campaign, found 5953 cases that presented lesions by $S$. mansoni, reaching a rate of $2.3 \%$ of all samples. The states that presented more prevalence rates were Alagoas $(11.4 \%)$, Sergipe (10.2\%), and Pernambuco (9.4\%). At the end of the 1940s Rodrigues da Silva (1949) made an extensive review about the disease of "Manson Pirajá da Silva", where he gathered all information known about the issue until that time.

The first national coprologic inquiry was conducted by Pellon and Teixeira (1950, 1955), from the Sanitarian Organization Division, Ministry of Health, and it revealed the geographic distribution of schistosomiasis in Brazil. During the decades of 50 and 60, many pioneering works were developed by Pessoa et al. $(1953,1955,1957)$ in Brazilian Northeast, Brener and Mourão (1956), Rodrigues da Silva (1957), Klotzel $(1962,1963)$ Katz and Brener (1966), Barbosa (1966, 1968), Prata and Schroeder (1967), and Prata and Bina (1968), about morbidity and disease evolution, in areas of Minas Gerais, Alagoas, Pernambuco, and Bahia and many others cited by Coura et al. (1980-1992), which resume epidemiological, laboratorial and clinical studies about the disease until that time.

More recently, Katz (1992, 1998) Coura et al. (1992, 1995), Bina (1992) Barbosa and Coimbra Jr. (1992), Kloetzel (1992), Barbosa (1995), and Coura (1995) reviewed the epidemiological situation and suggested controlling actions for disease in Brazil, while Hiroshi Kano (1992) and Amaral and Porto (1994) analyzed the controlling actions adopted by National Health Foundation (Fundação Nacional de Saúde - Funasa).

\section{EFFORTS AND DIFICULTIES OF SCHISTOSOMIASIS CONTROL}

The following actions, isolated or combined, could be adopted in the attempt to control schistosomiasis: (1) intermediary hosts' control through molluscicides or biological methods; (2) improvement of basic sanitation conditions and potable water supply; (3) sanitary education for exposed population; (4) individual or massive treatment of people in areas of high prevalence; (5) individual protection against penetration of cercarias; (6) vaccine for exposed people, if there is an efficient one.

One of the greatest public health problems in countries where the disease is highly endemic is schistosomiasis control. Such is the case of Brazil, for the following reasons: (a) intermediary hosts large dissemination and their escape mechanisms from molluscicides and from biological control, besides high costs and low efficacy; (b) high costs associated with implementation of sanitary conditions and water supply and the intense contact of rural population with polluted water, outside dwellings, in particular, in agricultural and fishing activities or other eventual activity; (c) the long time needed for sanitary education and for the community to adhere to controlling programs; (d) individual or massive treatment has been shown efficient for controlling the morbidity, but not for reducing prevalence due to reinfections; (e) individual protection is unlikely, except for specific groups of exposed people; (f) until the present days, there is not an effective vaccine for preventing schistosomiasis.

The pioneering works about selective treatment of large-scale schistosomiasis, such as those by Heraldo Maciel (1929), Get Jansen (1946), Hoel Sette (1953), and 
Rodrigues da Silva (1958) were very important. Still using trivalent antimonial, they contributed enormously for knowledge about chemotherapy results and difficulties when it is used as a therapy for schistosomiasis control. Since then, it was also possible to evaluate that schistosomiasis specific treatment is an important measure to control the disease in population groups far from endemic areas. Despite of its toxic effects, of the difficulties regarding massive treatment and reinfections, which hinder disease control in endemic areas, it was undoubtedly demonstrated that this type of treatment was able to reduce severe forms of disease (Jansen 1946), a fact that was confirmed by Kloetzel $(1962,1963)$.

After the discovery of less toxic, single-dose drugs, such as Hycanthone, it was possible to develop larger scale campaigns, as those developed in São Paulo and other states. Unfortunately, however, these campaigns' outcomes were not properly evaluated. Prata (1976) reviewed all Brazilian experience on schistosomiasis massive treatment in experimental field researches, until that time; Bina and Prata $(1970,1974)$, in Bahia, and Katz et al. (1978), in Minas Gerais, demonstrated a possibility to reduce infection rates, parasite load, and disease evolution for severe forms, in endemic areas, due to repetitive treatment with Hycanthone; a fact they understood as a result of resistance increase for reinfection among repeatedly treated individuals.

During the 1970s, there appeared two other drugs, oxammiquine and praziquantel, and, as they could be used in one single dose, with high levels of parasitological cure and low toxicity, they were considered an important step not only regarding schistosomiasis individual therapeutic, but also as a possibility of large scale usage, including disease control programs. These drugs proved to be particularly effective in controlling morbidity by reducing parasite load and reinfection rates, when repeatedly used at endemic areas (Coura et al. 1980, 1992, Bina \& Prata 1980, Katz et al. 1980, Prata et al. 1980, Coura 1986). However, all of them show a reinfection trend and an increase of parasite load after a time, when there is therapeutic interruption, being more intense in children than in adults, indicating that therapy alone is not able to interrupt transmission. This fact was very well demonstrated during an evaluation attempt of Special Schistosomisis Control Program (Pece), in Paraíba, after ten years of program installation (Coura et al. 1987).

\section{THE MINISTRY HEALTH SCHISTOSOMIASIS CONTROL} PROGRAMS IN BRAZIL

\section{Pilot Plan}

In 1965, Rodrigues da Silva, who was then the director of Rural Endemics National Institute (Instituto Nacional de Endemias Rurais - Ineru), established the Pilot Plan for schistosomiasis control at experimental areas in Pernambuco, Bahia, Minas Gerais, and Rio de Janeiro, coordinated, respectively, by Drs Frederico Simões Barbosa (in São Lourenço da Mata), Aluízio Prata (in Caatinga do Moura), Marcelo Coelho (in Belo Horizonte), and Solon de Camargo (in Jacarepaguá, RJ). The plan aimed to evaluate the efficacy and cost-benefits aspects of basic sanitary conditions, potable water supply, and sanitary edu- cation, the use of molluscicides and of massive treatment, in an isolated or associated way. The coordination of sanitary education was conducted by Mrs Hortência de Holanda; Dr Ernest Paulini coordinated the evaluation of molluscicide usage. The plan was designed to last five years, but after Prof. Rodrigues da Silva's death, it was interrupted, in 1968. Even so, the following advantages were registered: (a) it was the first time that there was a plan of actions, coordinated at different country areas, by different researchers, for disease control; (b) it was generated important information, in particular those about schistosomiasis evolution, basic sanitary conditions and water supply in São Lorenço da Mata, about massive treatment in Caatinga do Moura, and about treatment related to the usage of molluscicides in Belo Horizonte and Jacarepaguá. The respective coordinators consolidated all these experiences within many years.

\section{The Special Schistosomiasis Control Program (Pece)}

The Pece, developed by the Ministry Health was initiated in 1976, in eight states of Brazilian Northeast, and its objective was to reduce the prevalence of $S$. mansoni infection to $4 \%$. The control actions included population massive treatment with oxammiquine, regular application of molluscicides in "epidemiological important" transmission foci, sanitary education, and improvement of basic sanitary conditions and water supply.

During Pece's preparation phase, 42.178 breeding places of mollusks were localized in Brazilian Northeast and 739.995 coproscopic exams were made, indicating a prevalence of 22.8\% (Machado 1982). During Pece's operational phase (1977-1979), 1.733.677 feces exams were made in students between 7 and 14 years old, showing a infection prevalence of $14.4 \%$. Therefore, $2.473 .672 \mathrm{ex}$ ams were accomplished during both phases (preparation+ operational). During Pece's development, it was adopted the following schemes: in places where prevalence achieved more than $20 \%$, it was adopted massive treatment for population over two years old; if prevalence stayed between 5 and $20 \%$, the treatment was administered to population between 5 and 35 years old; and, if prevalence was lower than 5\%, only positive cases were treated. This strategy seemed a little complex and empiric for us, but it was accomplished. Mollusks' breeding places were always treated with molluscicides that were rarely combined with other physical method. Basic sanitary conditions meant just a sinkhole installation and water supply, and sometimes public laundries, according to FSESP (Special Public Health Services Foundation) availability. The massive treatment were made by Sucam (Superintendence of Public Health Campaigns). Both institutions, FSESP and Sucam belongs to the Ministry of Health. Until December 1979, 2.699 .703 individuals had already been treated, and 3.409.789 had yet to be treated, according to the adopted strategy.

Because of the program's diversity and as each focus had its proper dynamic features, the plan presented different success levels. In this way, each state team took their own decisions, what has generated too many evaluations of the whole program and, consequently, its extinction in 1980. In 1982, ex-Minister Almeida Machado, 
the program creator and great enthusiast, published an analysis emphasizing, obviously, its positive aspects (Machado 1982).

\section{Schistosomiasis control within the period of 1980 to 1989}

This period may be divided in two phases: from 1980 to 1984 , the program lost its force, went through a process of decentralization and faced restrictions for massive chemotherapy. The activities associated to individual attention were transferred to State Health Secretaries, Inamps (National Institute for Medical Assisttance), FSESP, and Sucam. At state level, according to resource availability, the unities had more decision power for modifying centralized norms. As for the second phase, from 1985 to 1989 , there was an attempt of restructuring the program by dividing it in areas, such as: (a) primary endemic - those with long term transmission and high prevalence rates; (b) secondary endemic - those with recent transmission, due to professional activities; (c) isolated foci - with localized transmission; (d) vulnerable areas those which present risk of transmission. Based on this division, it was established the following strategies for each one of them. For primary endemic areas, it was indicated a biannual massive treatment, where prevalence in children from 7 to 14 years old was higher than $50 \%$; when prevalence stood between 25 and $50 \%$, population from 2 to 14 years old was submitted to selective treatment; and when prevalence was lower than $25 \%$, just infected people was treated. In addition, there was molluscicides application on "epidemiological important" foci as well as improvement of sanitary conditions and community mobilization. For secondary endemic areas, the same methodology should be applied, based on prevalence indicated through exams on $20 \%$ of the whole population with less than 1000 inhabitants and on $10 \%$ of communities with more than 1000 inhabitants. For isolated foci, the objective was to interrupt transmission and avoid expansion of the foci, through biannual coproscopic inquiries of the whole population; treatment of infected people; use of molluscicides on transmission foci; and community participation. On vulnerable areas, the objective was to prevent the establishment of a focus, through population coproscopy, treatment for infected migrants and a vigilance system. Silveira (1989) resumed the program objectives in this way: (a) suppression of severe forms through precocious treatment; (b) prevalence reduction; (c) interruption of transmission on isolated foci; and (d) prevention of foci installation on vulnerable areas.

\section{Schistosomiasis control within the period of 1990 to 2002}

From 1990 on, the National Health Foundation (Funasa), formed by the association of Sucam and FSESP, started to direct the Schistosomiasis Control Program (PCE), as anyother programs for endemic diseases from the Ministry of Health, aiming the following objectives: (a) to reduce the prevalence of each locality to less than $25 \%$, since the majority of severe forms usually occurred in areas with a prevalence higher than this; (b) to reduce severe forms of schistosomiasis and subsequent obits through systematic treatment; (c) to eliminate transmission of isolated foci; and (d) to avoid endemic expansion, combating illness transmission causes by using intervention techniques, such as: (1) sanitary education; (2) basic sanitation; (3) coproscopic diagnosis and treatment of carriers; (4) control of mollusks. Amaral and Porto (1994) made a complete review of the PCE, historic features, evolution, status and determinants until that date, fundaments and objectives, control techniques and methods, results achieved until then and, finally, perspectives for disease control.

\section{TODAY SITUATION: RESULTS SYNTHESIS AND CON- CLUSIONS}

The present review analyzes available data from Schistosomiasis Control Program, directed by the Secretary of Health Vigilance, Ministry of Health. Initially, the analysis focused on global data by year, from 1977 to 2002, investigating the prevalence of infection during a period of 26 years (Table I). Later, a comparison study was made in order to verify the prevalence by federative state, in two different periods, from 1980 to 1989 and from 1990 to 2002 (Table II), according to the program different phases.

As can be seen in Table I and Fig. 3, there was a dramatic reduction of prevalence from 1977 to 1979 , probably due to Pece. The prevalence continued to diminish, in a moderate gradation, though irregular way, from 1980 to 1989, when it achieved 5.48\%. From 1990 on, it was observed an also irregular period of ascension, until the rate of $11 \%$, between the years of 1993 and 1995 . Then, it started

TABLE I

Population examined and positive for schistosomiasis by year, Brazil, 1977 to 2002

\begin{tabular}{|c|c|c|c|}
\hline Year & $\begin{array}{c}\text { Population } \\
\text { examined }\end{array}$ & $\begin{array}{c}\text { Population } \\
\text { positive }\end{array}$ & $\%$ \\
\hline 1977 & 443.591 & 103.409 & 23.31 \\
\hline 1978 & 626.657 & 86.111 & 13.74 \\
\hline 1979 & 663.429 & 59.905 & 9.03 \\
\hline 1980 & 1.684 .615 & 164.860 & 9.79 \\
\hline 1981 & 1.840 .626 & 172.242 & 9.36 \\
\hline 1982 & 1.732 .907 & 136.882 & 7.90 \\
\hline 1983 & 2.096.268 & 184.149 & 8.78 \\
\hline 1984 & 2.347 .810 & 198.025 & 8.43 \\
\hline 1985 & 2.697.910 & 223.609 & 8.29 \\
\hline 1986 & 1.878 .728 & 138.481 & 7.37 \\
\hline 1987 & 1.406 .844 & 90.001 & 6.40 \\
\hline 1988 & 1.364 .606 & 82.962 & 6.08 \\
\hline 1989 & 1.395 .202 & 76.412 & 5.48 \\
\hline 1990 & 1.802 .675 & 150.934 & 8.37 \\
\hline 1991 & 1.900 .761 & 134.103 & 7.06 \\
\hline 1992 & 2.353 .970 & 203.207 & 8.63 \\
\hline 1993 & 2.354.390 & 274.084 & 11.64 \\
\hline 1994 & 2.559 .051 & 283.369 & 11.07 \\
\hline 1995 & 2.715 .259 & 300.484 & 11.07 \\
\hline 1996 & 2.731 .765 & 248.267 & 9.09 \\
\hline 1997 & 2.791 .828 & 291.315 & 10.43 \\
\hline 1998 & 2.150 .912 & 182.910 & 8.50 \\
\hline 1999 & 2.076 .677 & 175.585 & 8.46 \\
\hline 2000 & 1.360 .608 & 90.874 & 6.68 \\
\hline 2001 & 966.244 & 62.136 & 6.43 \\
\hline 2002 & 992.953 & 53.953 & 5.43 \\
\hline
\end{tabular}

Source: Ministry of Health, Brazil 


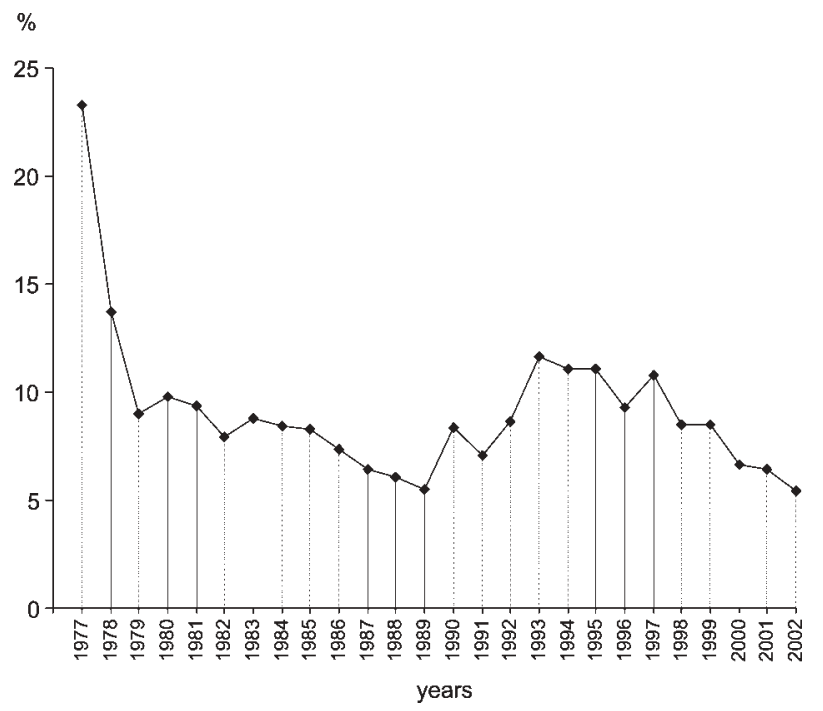

Fig. 3: prevalence of schistosomiasis in Brazil from 1977 to 2002

to decrease again, until the rate of $5.43 \%$, in 2002 . It must be observed that, in the triennium of 1987 to 1989 , the registered rate was as low as that obtained ten years later, in the triennium of 2000 to 2002, when it achieved 5.43\%. In this way, no consistent conclusions could be made to explain the alternation of prevalence rates during all this time.

We did not find any little reduction in prevalence, in average indexes, if compared longer periods, such as the period from 1980 to 1989, when the program was operated by Sucam, and 1990 to 2002 (Table II), when it was coordinated by Funasa, considering data by federative state.
The indexes found were $12.5 \%$, from 1980 to 1989 , and $9.2 \%$, from 1990 to 2002 , achieving an average rate of $11.5 \%$. This fact is similar in the analysis by state, except for Alagoas, where there was an increase of prevalence rate from $16.7 \%$, in the period from 1980 to 1989 , to $19.8 \%$, in the period from 1990 to 2002, and for Federal District, where there was an increase from $0.9 \%$ to $20.8 \%$. In the other states, there were small variations, without significance. In Federal District, the increase of prevalence rate was due to strategy changes in the process of cases localization, in the second period, which was directed to cases localized through a search of infected patients and its family and relatives. In Rondônia, there are no transmission cases, which are imported and detected on vigilance.

The reduction of morbi-mortality resulting from schistosomiasis is evident and it was due to the implementation of SCP and the massive and individual use of oxammiquine and praziquantel. This fact is represented also by the decrease in hospitalization cases (Fig. 4).

As a conclusion, we may state that Schistosomiasis Control Program was very successful in controlling the disease morbidity, it was relatively successful in reducing infection prevalence and isolated foci, but did not interrupt transmission, nor reduced prevalence rate to less than $5 \%$, nor avoided the occurrence of new foci in Santa Catarina, Federal District, Goiás, and Rio Grande do Sul. Finally, we confirm the conclusions and recommendations of Coura and Camillo-Coura (1980) and Amaral and Porto (1994), as for the perspectives of schistosomiasis control in Brazil: (a) no method is able, in an isolated way, to control schistosomiasis and every control program should consider the need of multidisciplinary application of existing methods; (b) the main methods for long term control of infection are the implementation of basic sanitation

TABLE II

Prevalence of schistomiasis in Brazil, by state, considering the Control Programs from 1980-1989 and 1990-2002

\begin{tabular}{|c|c|c|c|c|c|c|}
\hline \multirow[b]{2}{*}{ States } & \multirow{2}{*}{$\begin{array}{c}\text { Average of faeces } \\
\text { exams/year }\end{array}$} & \multicolumn{5}{|c|}{ Percentage of positivity } \\
\hline & & Average & $1980-1989$ & & & 1990-2002 \\
\hline Alagoas & 98.315 & 19,2 & 16,7 & & & 19,8 \\
\hline Goiás & 2.777 & 3,1 & & $(1995$ & $-2002)$ & \\
\hline Sergipe & 51.229 & 17,3 & 16,3 & & & 17,7 \\
\hline Pernambuco & 111.993 & 14,7 & 14,7 & & & 14,6 \\
\hline Distrito Federal & 8,885 & 1,70 & 0,9 & & & 20,8 \\
\hline Bahia & 512.218 & 10,2 & 10,9 & & & 9,7 \\
\hline Espírito Santo & 94.248 & 11,1 & 14,0 & & & 8,4 \\
\hline Paraíba & 135.199 & 9,7 & 10,4 & & & 9,1 \\
\hline Minas Gerais & 294.730 & 10,1 & 10,4 & & & 10,1 \\
\hline Rio Grande do Norte & 87.508 & 5,1 & 4,8 & & & 5,3 \\
\hline Maranhão & 145.616 & 5,1 & 5,8 & & & 4,5 \\
\hline Rondônia & 15.681 & 2,1 & & (1994 & $-2002)$ & \\
\hline Paraná & 58.454 & 2,4 & 2,4 & & & 2,4 \\
\hline Ceará & 170.302 & 1,9 & 1,8 & & & 1,9 \\
\hline Rio de Janeiro & 36.615 & 1,4 & 1,5 & & & 1,4 \\
\hline Santa Catarina & 7.999 & 0,3 & 0,3 & & & 0,4 \\
\hline Pará & 87.420 & 1,1 & 1,2 & & & 1,0 \\
\hline Piauí & 22.020 & 0,3 & 0,4 & & & 0,04 \\
\hline Average for the country & $1.929,733 /$ year & 11,5 & 12,5 & & & 9,2 \\
\hline
\end{tabular}

Source: Ministry of Health, Brazil 


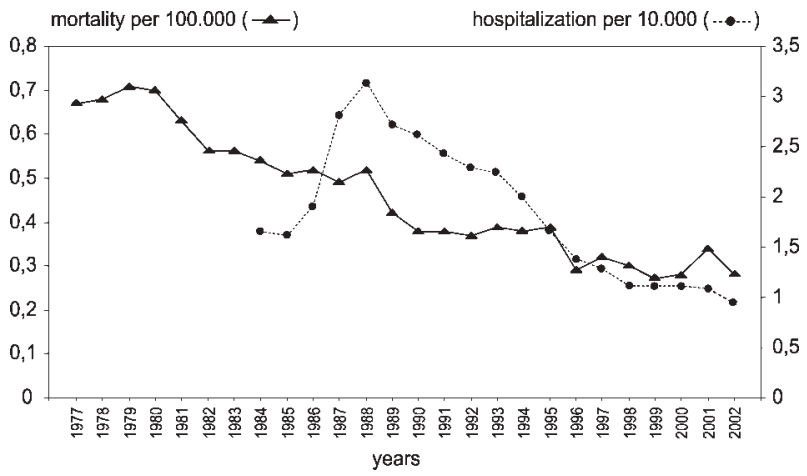

Fig. 4: reduction of morbi-mortality by schistosomiasis and decrease of hospitalization by this disiase in Brazil

conditions, potable water supply, as well as sanitary education and community participation; (c) specific treatment in endemic areas associated to intermediary hosts control in "epidemiological important" foci is extremely relevant regarding short term morbidity control, though not sufficient to interrupt disease transmission; (d) although schistosomiasis control, in a country like Brazil, with great vectors dissemination and population mobilization, is a difficult process, it is possible through intensification, adjustment, and continuity of programs in long term; (e) it is necessary to develop a critical analysis of schistosomiasis control experience in Brazil, in order to redirect the program in an effective way, aiming to achieve only residual levels of infection for the next 20 or 30 years or, even better, its full control.

\section{REFERENCES}

Amaral RS, Porto MAS 1994. Evolução e situação atual da esquistossomose no Brasil. Rev Soc Bras Med Trop 27 (Supl. III): 73-90.

Araujo JD 1986. A pesquisa em esquistossomose no Brasil. In Modernos Conhecimentos sobre Esquistossomose Mansônica. Biblioteca da Academia Mineira de Medicina 14: 918.

Barbosa FS 1966. Morbidade da esquistossomose. Rev Soc Bras Malar D Trop 1: 3-159.

Barbosa FS 1968. Esquistossomose mansônica: repercussões sobre a comunidade. Rev Soc Bras Med Trop 2: 153-156.

Barbosa FS 1995. Determination and control of schistosomiasis in Brazil: perspectives and control. Mem Inst Oswaldo Cruz 90: 257-260.

Barbosa FS, Coimbra Jr CEA 1992. Alternative approaches in schistosomiasis control. Mem Inst Oswaldo Cruz 90 (Suppl. IV): 215-220.

Bilharz TM 1852. Fernere Beobachtungen uber das die Pfortader des Menschen bewohnende Distonum haematobium und sein zu gewissen. Wschift Zol Leipzig 4: 72-76.

Bina JC 1992. Specific therapy in the control of schistosomiasis. Mem Inst Oswaldo Cruz 87 (Suppl. IV): 195-202.

Bina JC, Prata A 1970. Hycanthone no tratamento da esquistossomose em uma área rural com baixos índices de transmissão da doença. Gaz Méd Bahia 70: 127-130.

Bina JC, Prata A 1974. An atempt to control schistosomíasis in an endemic area by use Hycanthone as chemotherapeutic agent. Rev Soc Bras Med Trop 8: 217-222.
Bina JC, Prata A 1980. Oxammiquine in the treatment of schistossomiasis in a population in area with low endemicity. Rev Inst Med Trop São Paulo 22 (Supl. 4 ): 94-97.

Brener Z, Mourão OG 1956. Observações sobre a forma hepatoesplênica da esquistossomose mansoni em Minas Gerais. Rev Malar D Trop 8: 511-517.

Coura JR 1986. O papel da terapêutica específica no controle da esquistossomose mansoni. In Modernos Conhecimentos sobre Esquistossomose Mansônica. Biblioteca da Academia Mineira de Medicina 14 : 33-38.

Coura JR 1995. Control of shistosomiasis in Brazil: perspectives and proposal. Mem Inst Oswaldo Cruz 90: 257-260.

Coura JR, Camillo-Coura L 1980. Perspectivas de controle da esquistossomose com especial referência ao tratamento em massa. Rev Soc Bras Med Trop 13: 157-160.

Coura JR, Argento CA, Conceição MJ, Lewis EM, Santo ML, Magalhães P 1980. Field experience with oral oxammiquine in the treatment of schistossomiasis. Rev Inst Med Trop São Paulo 22 (Supl. 4): 77-84.

Coura JR, Conceição MJ, Menezes AP, Santos ML, Mendonça MZG 1983. Morbidade da esquistossomose no Brasil. II. Estudo de quatro áreas de campo nos estados de Minas Gerais, Sergipe e Paraíba. Mem Inst Oswaldo Cruz, 78: 111.

Coura JR, Conceição MJ, Pereira JB 1984. Morbidade da esquistossomose no Brasil. III. Estudo evolutivo em uma área endêmica no período de dez anos. Mem Inst Oswaldo Cruz, 79: 447-453.

Coura JR, Conceição MJ, Santos ML, Mendonça MZ, Cutrim RNM 1992. Cross-sectional and evolutive studies of schistosomiasis mansoni in untreated and mass treated endemic areas in the Southeast and Northeast of Brazil. Mem Inst Oswaldo Cruz 87 (Suppl. IV): 175-182.

Coura JR, Mendonça MZG, Madruga JP. 1987. Tentativa de avaliação do Programa Especial de Controle da Esquistossomose (Pece) no Estado da Paraíba, Brasil. Rev Soc Bras Med Trop 20: 67-76.

Coura JR, Queiroz GC, Florêncio CG, Argento CA, Coutinho SG, Figueiredo N, Wanke B, Camilo-Coura L 1982. Morbidade da esquistossomose no Brasil. I Estudo de 4.652 casos observados no Rio de Janeiro de 1960 a 1979. Mem Inst Oswaldo Cruz 77: 69-88.

Fuji I 1847. Katayama disease. Katayamaki: Chugai Iji Shimpo 691: $55-56$

Hiroshi Kano P 1992. Measures for control of schistosomiasis adopted by the Fundação Nacional de Saúde. Mem Inst Oswaldo Cruz 87 (Suppl. II): 315-319.

Jansen G 1946. Profilaxia experimental da esquistossomose de Manson. Mem Inst Oswaldo Cruz 44: 549-578.

Katz N 1992. Brazilian contribuition to epidemiology aspects of schistosomiasis mansoni. Mem Inst Oswaldo Cruz 87 (Suppl. IV): 1-9.

Katz N 1998. Schistosomosis control in Brazil. Mem Inst Oswaldo Cruz 93 (Suppl. I): 33-35.

Katz N, Brener Z 1966. Evolução clínica de 112 casos de esquistossomose mansoni observados após 10 anos de permanência em focos endêmicos de Minas Gerais. Rev Inst Med Trop São Paulo 8: 519-526.

Katz N, Rocha RS, Pereira JP 1980. Schistosomosis control in Peri-Peri (Minas Gerais, Brazil) by repeated clinical tratment and muluscicide application. Rev Inst Med Trop São Paulo 22 (Suppl. 4): 85-93.

Katz N, Zicker F, Rocha RS, Oliveira VR 1978. Reinfection of pacients in shistosomiasis mansoni endemic area after specific treatment. Rev Inst Med Trop São Paulo 20: 273-278.

Kloetzel K 1962. Aspectos Epidemiológicos da Esquistossomose em uma População de Pernambuco. Suas Correlações 
Clínicas, Thesis, Universidade de São Paulo, São Paulo, $119 \mathrm{pp}$.

Kloetzel K 1963. Some quantitative aspects of diagnosis and epidemiology in schistosomiasis mansoni. Am J Trop Med Hyg 12: 334-347.

Kloetzel K 1992. Some personal views on the control of schistosomiasis mansoni. Mem Inst Oswaldo Cruz 90 (Suppl. IV): 221-226.

Leiper RT 1915. Report on the results of the bilharzias mission in Egypt, 1915. Part I. Transmission. J R Army Med Corps 25: $1-55$.

Lutz A 1916. Observações sobre a evolução do Schistosoma mansoni. Brasil Méd 30: 385-387.

Lutz A 1919. O Schistosoma mansoni e a schistosomose segundo observações feitas no Brasil. Mem Inst Oswaldo Cruz 11: 121-155.

Lutz A, Penna O 1918. Estudos sobre a schistossomose feitos no norte do Brasil por uma comissão do Instituto Oswaldo Cruz. Relatório e notas de viagem apresentadas. Mem Inst Oswaldo Cruz 10: 83-94.

Maciel H 1924. Algumas notas em torno do tratamento da schistosomose intestinal. Sci Méd 3: 3-24.

Maciel H 1925. Contribuição para o Estudo da Schistosomose Intestinal, Imprensa Naval, Rio de Janeiro, 147pp.

Maciel H 1929. O tratamento da esquistossomose intestinal no Hospital da Marinha. Sci Med 7: 20-24.

Machado P 1982. The Brazilian Program for Schistosomiasis Control, 1975-1979. Am J Trop Med Hyg 31: 76-86.

Madureira Pará 1949. The distribution of certain diseases in Brazil as indicate by data obtained through viscerotomy. I The incidence of Schistosoma mansoni lesions in material collected from 1937 to 1946. Mem Inst Oswaldo Cruz 47: 521-534.

Manson P 1902. Report of a case of bilharzia from West Indies. Brit Med J 2: 1894-1995.

Miyari K, Suzuki M 1914. The intermediate host of Schistosoma japoniam Katsurada. Mitt Med Fak Kaiser University Kуизи 1: 187-198.

Paraense WL 1966. Biomphalaria amazonica and B. cousini; two new species of Neotropical planorbid mollusc. Rev Bras Biol 26: 115-126.

Paraense WL 1981. Biomphalaria occidentalis n. sp. from South América. Mem Inst Oswaldo Cruz 76: 199-211.

Paraense WL 1986. Distribuição dos caramujos no Brasil. In Modernos Conhecimentos sobre Esquistossomose Mansonica no Brasil. Biblioteca da Academia Mineira de Medicina 14: 117-128.

Pellon AB, Teixeira I 1950. Distribuição geográfica da esquistossomose no Brasil, Divisão de Organização Sanitária,
Ministério da Saúde, Rio de Janeiro, 24 pp.

Pellon AB, Teixeira I 1955. O Inquérito Helmintológico Escolar em Cinco Estados das Regiões Leste, Sul e Centro-oeste, Divisão de Organização Sanitária, Ministério da Saúde, Rio de Janeiro, 14 pp.

Pessoa SB, Amorim JP 1957. Contribuição para a história natural da esquistossomose mansônica no Nordeste brasileiro e sugestões para sua profilaxia. Rev Bras Malar Doenç Trop 9: 5-18.

Pessoa SB, Barbosa PR 1953. Notas sobre a epidemiologia da esquistossomose mansônica no Estado de Sergipe. Rev Méd Cir S Paulo 13: 147-154.

Pessoa SB, Silva LHP, Costa L 1955. Observações sobre a epidemiologia da esquistossomose no Estado da Paraíba. Rev Bras Malar Doenç Trop 7: 305-310.

Pirajá da Silva MA 1908. Contribuição para o estudo da schistosomíase na Bahia. Brasil Med 22 : 281-283.

Prata A 1976. Experience in Brazil with the use of available schistosomicides in mass treatment campaigns. Rev Soc Bras Med Trop 10: 355-360.

Prata A, Bina JC 1968. Development of the hepatoesplenic form of schistosomiasis (A study of 20 patients observed during a five year period). Gaz Med Bahia 68: 49-60.

Prata A, Bina JC, Barreto AC, Alecrim MG 1980. Attempt to control schistosomiases transmission by oxammiquine, in an hyperendemic locality. Rev Inst Med Trop São Paulo 22 (Supl. 4): 65-72.

Prata A, Schroeder S 1967. A comparison of whites and negroes infected with Schistosoma mansoni. Gaz Med Bahia 63: 93-98.

Rodrigues da Silva J 1949. Estudo sobre a Esquistossomose Mansoni (Doença de Manson-Pirajá da Silva), Thesis, Universidade Federal Rio de Janeiro, Rio de Janeiro, 452pp.

Rodrigues da Silva J 1957. Valor e importância do tratamento específico da esquistossomose no campo da profilaxia. Rev Bras Med 14: 514.

Rodrigues da Silva J 1958. Avaliação dos resultados da terapêutica específica da esquistossomose em uma campanha de saúde pública no Brasil. Proceeding 6th Intern Cong on Trop Med and Malaria, Lisbon, PY: 89-100.

Sambon LW 1907. Remarks on Schistosoma mansoni. Am J Trop Med Hyg 10: 303-304.

Sette H 1953. O Tratamento da Esquistossomose à Luz da Patologia Hepática (Estudo Clínico), Thesis, Universidade Federal de Pernambuco, Recife, 220 pp.

Silveira AC 1989. Controle da esquistossomose no Brasil. Mem Inst Oswaldo Cruz 84 (Suppl. I): 51-102.

WHO-World Health Organization 1993. The Control of Schistosomiasis, Technical Repor Series, 83, 86pp. 
